\title{
Do STAD Learning Method Can Improve Students' Learning Outcomes on Social Science?
}

\author{
Fatkul Anam ${ }^{1}$, Dhana Qurrota A'yun ${ }^{2}$, Nur Asitah ${ }^{3}$, Agung Purnomo ${ }^{4}$, \\ Muawwinatul Laili ${ }^{5}$ \\ ${ }^{1}$ Universitas Wijaya Kusuma Surabaya, ${ }^{2,3,5}$ Universitas Nahdlatul Ulama \\ Sidoarjo, ${ }^{4}$ Bina Nusantara University \\ 11 fatkulanam@yahoo.com, ${ }^{2}$ dhanaqurrota01@gmail.com, ${ }^{3}$ nurasitah@unusida.ac.id \\ ${ }^{4}$ agung.purnomo@binus.ac.id, ${ }^{5}$ winalaily1984@gmail.com
}

\begin{abstract}
Some students in elementary schools face some problems related to the students' learning focus and interest in a social science subject. The Student Teams Achievement Divisions (STAD) of the cooperative learning model on educational management divides students into small teams to discuss and help each other. This study purposes to improve elementary school students' learning outcomes focus on social science subjects using the STAD learning method. The implementation of the STAD learning method in this research is based on the Classroom Action Research model which was developed by Kurt Lewin. This model involves four stages, namely; planning, acting, observing, and reflecting. The result of this study proves that the applying of the STAD learning method on social science subjects in fourth-grade elementary students can improve the students' learning outcomes, role, enthusiasm, and cooperation between others in the learning process. It can be seen from the increase of students' learning outcomes completeness reach up to $80,9 \%$.
\end{abstract}

Keywords: Learning Method, Learning Outcomes, STAD

\begin{abstract}
Abstrak
Beberapa siswa sekolah dasar menghadapi berbagai masalah yang berkaitan dengan fokus dan minat belajar siswa pada mata pelajaran Ilmu Pengetahuan Sosial (IPS). Student Teams Achievement Divisions (STAD) sebagai salah satu tipe dari model pembelajaran kooperatif dalam manajemen pendidikan membagi siswa ke dalam kelompok-kelompok kecil untuk berdiskusi dan saling membantu satu sama lain. Kajian ini bertujuan untuk meningkatkan hasil belajar siswa sekolah dasar yang fokus pada mata pelajaran IPS dengan menggunakan metode pembelajaran STAD. Penerapan metode pembelajan STAD dalam penelitian ini didasarkan pada model penelitian tindakan kelas yang dikembangkan oleh Kurt Lewin. Model ini mencakup empat tahapan, yaitu merencanakan, berbuat, mengamati, dan merefleksikan. Hasil penelitian ini membuktikan bahwa penerapan metode pembelajaran STAD pada mata pelajaran IPS siswa kelas IV SD dapat meningkatkan hasil belajar siswa, peran, semangat, dan kerjasma antar siswa dalam proses pembelajaran. Hal ini dapat
\end{abstract}


dilihat dari peningkatan ketuntasan hasil belajar siswa yang mencapai angka $80,9 \%$.

\section{Kata Kunci: Hasil Belajar, Metode Pembelajaran, STAD}

\section{Introduction}

The elementary grades are considered to be the pivotal point for the development of science learning trajectories and achievement gaps. ${ }^{1}$ Most students in some elementary schools have problems and difficulties in focusing their concentration on learning social science subjects. ${ }^{2}$ Students feel bored when studying social science subjects and they think that this subject is not interesting. ${ }^{3}$ The learning objectives of social science in elementary school are focused on three aspects, they are; cognitive, affective, and psychomotor. ${ }^{4}$ By studying social science subjects, students are expected to be more empathetic towards the surrounding environment. They will be more caring and sociallyminded people in their social life and community. The survey reports clearly show the growing demand for humanities subjects. So, there is a great responsibility on the shoulders of teachers in sociology to keep the trend going. ${ }^{5}$ Besides that, the goal of social science subjects in elementary school is to prepare the students as the qualified generation who can cooperate with others in solving social problems. They also manage to make decisions and participate in the community, state life, and nation. ${ }^{6}$ In general, the educational process of this subject in elementary schools used cognitive and psychomotor approaches to be able to be achieved well but the affective aspect is still not optimal since the learning process tends to finish the material only. ${ }^{7}$ In learning social science, the teachers often use the question and answer and lecture method. It makes students bored with the learning program.

\footnotetext{
${ }^{1}$ F. Chris Curran and James Kitchin, "Early Elementary Science Instruction: Does More Time on Science or Science Topics/Skills Predict Science Achievement in the Early Grades?," AERA Open 5, no. 3 (July 3, 2019): 233285841986108, https://doi.org/10.1177/2332858419861081.

2 Roli Bhatnagar, "'Challenges In Teaching And Learning Of Social Science -The Dual Perspective,"” PEOPLE: International Journal of Social Sciences 4, no. 3 (December 10, 2018): 519-32, https://doi.org/10.20319/pijss.2018.43.519532.

${ }^{3}$ Hamza AKENGIN and Meltem Elif CENDEK, "A Study of Students' Opinions About History Subjects in the Social Studies Curriculum," Journal of Literature and Art Studies 7, no. 10 (September 20, 2017), https://doi.org/10.17265/2159-5836/2017.10.016.

${ }^{4}$ Dadang Iskandar, Lutma Ranta Allolinggi, and Acep Roni Hamdani, "Analysis Learning Social Science Charged The Values Of Entrepreneurship In Primary School," Jurnal Pendidikan Dasar Indonesia 2, no. 1 (2017): 9-12.

${ }^{5}$ H Endayani, "Pengembangan Materi Ajar Ilmu Pengetahuan Sosial," Jurnal Program Studi Pendidikan Ilmu Pengetahuan Sosial FITK UIN SU Medan 1 (2017).

${ }^{6}$ Endayani.

7 Robyn M. Gillies, "Cooperative Learning: Review of Research and Practice," Australian Journal of Teacher Education 41, no. 3 (2016): 39-54.
} 
Based on preliminary observations made by researchers, the lack of enthusiasm of elementary school students in studying social science has an impact on students' final grade completeness. This can be seen from the decline in scores in existing social science subjects. This research works based on observations and interviews in one of the primary schools in Indonesia. Teachers of health humanities span a wide range of disciplines. ${ }^{8}$ Previous research conducted by researchers there illustrates that teachers are less able to present material attractively. Thus, the researchers concluded that this problem emerged as one of the main factors behind the incompleteness of the expected values in the educational process. The learning model in class should be chosen based on the students' needs. ${ }^{9}$

One contemporary learning model that could improve elementary school student learning outcomes on social science subjects is the cooperative learning model. Appropriate research methods are needed to provide an effective learning method approach for students. ${ }^{10}$ Johnson, Stanne, and Garibaldi ${ }^{11}$ stated the effectiveness of using the cooperative model to help the student in reaching the higher maximum score. Since the usage of the cooperative model makes the students take portion in discussions with peers effectively. A number of the features of using cooperative learning model are; (1) the usage of cooperative learning model can improve students' achievement and at the same time frame body improve cultural relationships, foster a helpful attitude, and support the views of others, (2) problems, and incorporate knowledge with experience. ${ }^{12}$ Thus, the goal of the cooperative learning model is to enhance the grade of learning and teaching and social science process. The cooperative learning model is defined as a series of techniques that support persons interact together to achieve certain goals or develop end products that are usually in certain content. Afterward, In the cooperative learning model, the teacher must control the class effectively, especially when students work in groups to

\footnotetext{
${ }^{8}$ Larry R. Churchill, “What Skills Should Be Taught in Health Humanities Education?,” Rupkatha Journal on Interdisciplinary Studies in Humanities 12, no. 6 (December 15, 2020), https://doi.org/10.21659/rupkatha.v12n6.01.

${ }^{9}$ Sayyida Hanim Ahida Suci et al., "Learning from Picture and Picture Action Research: Enhancement of Counting Ability on Division of Numbers for Primary School Students," in Journal of Physics: Conference Series (Aceh: IOP Publishing, 2018), https://doi.org/10.1088/1742-6596/1114/1/012044.

10 Akbar Iskandar et al., "The Effects of Multimedia Learning on Students Achievement in Terms of Cognitive Test Results The Effects of Multimedia Learning on Students Achievement in Terms of Cognitive Test Results," in Journal of Physics: Conference Series, vol. 1114 (IOP Publishing, 2018).

11 D Johnson et al., "Impact of Group Processing on Achievement in Cooperative Groups," Journal of Social Psychology 130 (1990): 507-16.

12 Robert E. Slavin, "Developmental and Motivational Perspectives on Cooperative Learning: A Reconciliation," Child Development 58 (1987): 1161-67.
} 
achieve learning objectives. ${ }^{13}$ The cooperative learning model can be interpreted as a teaching method that implements the teacher can manage students into little groups who interact to simply help one another understand academic material ${ }^{11}$ and continuum of students who interact in small organizations, so as that everyone may focus on jobs jointly determined by the teacher. ${ }^{14}$

There is a type of Cooperative learning model, Student Teams Achievement Divisions or STAD. The STAD kind of cooperative learning model is one of many cooperative learning models that divide students into little teams. Then students discuss to greatly help one other accomplish common goals. Next, there are individual tests to discover the outcomes of student understanding. There are rewarding and scoring as a consequence of the task done by students in the educational process. The determination of learning methods and media is closely related to the selection of the very most efficient and effective learning strategies in providing the learning experience needed to form the basic competencies of students. ${ }^{15}$ The STAD product was conceived by students from Johns Hopkins College and is recognized as the "Student Training Team". ${ }^{16}$ In teaching and learning activity, the teacher can use some learning methods which can develop students' activity and creativity. STAD is a cooperative learning approach in the learning and teaching process. ${ }^{17}$ The important theoretical views have been investigated within the past several two decades, specifically determination and cognitive idea on student understanding. ${ }^{18}$.

Research on the efficacy of the STAD learning process in language show that's STAD was able to increase the interpersonal and communication skills of bachelor students. STAD was claimed to be a good approach to the understanding subject matter and improving student attitudes. That research proves that it potentially produces

\footnotetext{
13 Anita Rakhman and Isry Laila Syatroh, “The Analysis Of Students' Team Achievement Divisions (STAD) Used In Learning Practice Of Translating And Interpreting," ELTIN Journal 3, no. 2 (2015).

${ }^{14}$ Micheal M Van Wyk, "The Effects of the STAD-Cooperative Learning Method on Student Achievement, Attitude and Motivation in Economics Education," Journal of Social Sciences 33, no. 2 (2017): 261-70, https://doi.org/https://doi.org/10.1080/09718923.2012.11893104.

15 A Zahroh, Membangun Kualitas Pembelajaran Melalui Dimensi Profesionalisme Guru (Bandung: Yrama Widya, 2015).

${ }^{16}$ S Sharan, “Cooperative Learning," Review of Educational Research 50, no. 2 (1995): 315-45.

${ }^{17}$ Robert E. Slavin, “Outcome-Based Education Is Not Mastery Learning," Educational Leadership 51, no. 6 (1994): 14-15.

${ }^{18}$ Muhammad Ishtiaq, Ali Zuraina, and Muhammad Salem, "The Effects of Student Teams Achievement Division (STAD) on Motivation of Saudi EFL Adult Learners," International Journal of Language Education and Applied Linguistics (IJLEAL) 3 (2015): 11-24, https://doi.org/10.15282/IJLEAL.V3.471.
} 
maximum results with the appropriate number of students in the study group. ${ }^{19}$ However, the previous study did not use social science lessons and used elementary school students' samples. This study posed a research question, do the STAD learning method can improve elementary school students' learning outcomes on social science?. Therefore, this study purposes to improve elementary school students' learning outcomes focus on social science subject using the STAD learning method. In terms of providing implications for knowledge, this study strengthens the STAD learning methods by Robert E. Slavin to improve student learning outcomes. ${ }^{20}$ As a practical implication, it gives preference to social studies learning methods for teachers, educators, policymakers, and school management. Social studies learning becomes more fun for students so that it has the opportunity to improve learning outcomes.

\section{Methods}

The research design of this study is a Classroom Action Research (CAR) that applied Student Teams Achievement Divisions or STAD learning method. This single case study was conducted in Keboguyang Elementary School, Sidoarjo, Indonesia. The research respondents were fourth-grader elementary students in the 2018/2019 school year. The main data were received from 14 boy and 7 girl students in a cycle during 2019 . Class Action Research can be understood as a process in analyzing some learning problems that appear in the classroom. This research design is conducted through the reflecting step to find the solution. ${ }^{21}$ In this study, the researcher applied the research model developed by Kemmis \& Mc Taggart. This research was conducted through four stages and the revision step..$^{22}$ Observations, interviews, tests, and documentation were used by the researcher as the research instrument to gather the data. ${ }^{23}$ The observation data were obtained by the researcher from the observation sheet that was used to observe all of the students' activities in the class. ${ }^{24}$

\footnotetext{
19 Rakhman and Syatroh, “The Analysis Of Students' Team Achievement Divisions (STAD) Used In Learning Practice Of Translating And Interpreting."

${ }^{20}$ Slavin, "Outcome-Based Education Is Not Mastery Learning."

21 Bagus Shandy Narmaditya, Winarning, and Dwi Wulandari, "Impact of Problem-Based Learning on Student Achievement in Economics Course," Classroom Action Research Journal 1, no. 1 (2017): 1-11, https://doi.org/10.17977/um013v1i12017p1.

22 Suharsimi Arikunto, Prosedur Penelitian (Jakarta: Rineka Cipta, 2013).

23 Herry Agus Susanto and Utami Murwaningsih, "Improving Students' Activity In Mathematics Communication Trough Metacognitive Learning Approach Based On Lesson Study,” International Journal of Education and Research 3, no. 2 (2015): 169-80.

${ }^{24}$ Yupik Puji Astuti, "The Use Of Student Team Achievement Division (STAD) To Improve The Students Reading Comprehension Practice," English Education Journal 4, no. 1 (2014): 2-8.
} 
Data analysis was using learning mastery individually as shown in formula (1). $\mathrm{LM}=$ learning mastery, $\mathrm{NS}=$ number of students, how many students who rating over $75, \mathrm{~N}=$ number of frequencies or number of an individual, and $\mathrm{N}=$ the number of students, and $\mathrm{f}=$ frequency sought percentage.

$$
\mathrm{LM}=(\mathrm{NS} / \mathrm{N}) \times 100 \%
$$

Students are considered mastery when attaining the Minimum Learning Mastery Standard (MLMS) that has been decided was $\geq 75$. The teacher's accomplishment indicator uses the classic achievement formula if the completeness of students reaches $85 \%$ of the sum overall level of students in a class. The researcher used formula (2) to analyze the classroom action research data. $\mathrm{P}=$ percentage of a number. $^{25}$

$$
\mathrm{P}=100 \%
$$

Table 1 includes the score criteria in the learning process which includes five groups to see the quantity of students' achievement that is been applied by the teacher in the learning process. ${ }^{26}$ Based on these data students are considered to be able to absorb learning well, if the value they get in their learning reaches $\geq 75$. Meanwhile, the value $\leq 75$ is considered less good when seen from the predetermined MLMS value.

\begin{tabular}{|c|c|c|}
\hline No & Level of success & Predicate of Success \\
\hline 1 & $86-100 \%$ & Very well \\
\hline 2 & $71-85 \%$ & Good \\
\hline 3 & $56-70 \%$ & Enough \\
\hline 4 & $41-55 \%$ & Less \\
\hline 5 & $<40 \%$ & Very Less \\
\hline
\end{tabular}

Table 1. Criteria of Student and Teacher Learning Process

\section{Discussion}

The research findings regarding the implementation of the STAD learning method in the subject of social sciences for students were shown in the following table 2 , descriptions of pre-cycle and cycle I. The findings of pre-cycle and cycle 1 data from students' learning outcomes, as has been revealed in table 2 .

\begin{tabular}{|c|c|c|c|c|c|}
\hline \multirow{2}{*}{ Cycle } & \multicolumn{2}{|c|}{ Mastery Students } & \multicolumn{2}{c|}{ Not Mastery Students } & \multirow{2}{*}{ Overage } \\
\cline { 2 - 5 } & Frequency & $\mathbf{\%}$ & Frequency & $\mathbf{\%}$ & \\
\hline Pre-Cycle & 7 & $33,3 \%$ & 14 & $66,7 \%$ & 66,5 \\
\hline Cycle I & 17 & $80,9 \%$ & 4 & $19,1 \%$ & 82,0 \\
\hline
\end{tabular}

${ }^{25}$ A Sudijono, Pengantar Evaluasi Pendidikan (Jakarta: Raja Grafindo, 2003).

${ }^{26}$ Z Aqib et al., Penelitian Tindakan Kelas Untuk Guru SD, SLB, Dan TK (Bandung: Yrama Widya, 2009). 
Tabel 2. Increasing Number of Students Who Achieve MLMS Per Cycle

\section{Description of Pre-Cycle}

The result of observation before applying the STAD method to the student's initial situations shows that the training ratings of students' social based on predicated on Minimum Learning Mastery Standard (MLMS) is low. Based on Learning Mastery (LM) students who reach the learning completeness is $33.3 \%$ with a total expertise achievement of 7 students. Meanwhile, students who cannot reach the learning completeness are 14 students with LM results of $66.7 \%$. The results of the information above suggest we can find still many students who've not reached MLMS. The MLMS score of fourth-grader of Keboguyang State Elementary School is 66,5 .

\section{Description of Cycle I Research Result}

In the first cycle, the researcher started to utilize the STAD learning design by decided the groups in the class. It is designed to make students more interested in various learning materials and experiences. The data in this cycle shows that the students' learning outcomes have increased significantly which means that the established completeness of learning outcomes is $80.9 \%$ and the average is 82,0 . Students who reach scored $<74$ were 4 students and those who scored $<74$ were 17 students.

The results indicated in Table 2. the increase in the number of students who completed MLMS per period shows that there was a significant increase in the number of students who achieved MLMS in Cycle I. How many students recognized the topic, originally only 7 students, or $33.3 \%$ transform to 17 students or $80.9 \%$. The data from cycle I mean that the application of learning techniques utilizing the STAD method can improve the students' learning outcomes significantly. That means that the targets of learning achievement have been reached and fulfilled. These learning outcomes have met an ideal LM typical because they have reached an LM score of $80.9 \%$ and a predicate of both conditions of the educational means of students and teachers.

It was found that the scores improved because students were motivated to understand social sciences subjects applying STAD learning practices that use teams. The curiosity and passion possessed by students to try and complete learning, especially in a variety of substances, is rising as well. Some various phases that influence the amount of students' accomplishment are the fact of curiosity, ability, 
amount of intelligence, learning traits possessed by children, along with the strategy used by teachers in classroom learning activities. Insufficient motivation, attention, activeness, and studying problems students have in learning is considered as the key reason for four students did not reach the minimum score criteria.

Based on the results obtained, it can be proved that the results of this study were in line with the results of previous studies. ${ }^{27}$ There is a significant effect of the STAD learning model on student achievement. This study obtained similar results that STAD was proven to increase the value and enthusiasm for learning possessed by students. These results can be seen from the improvements obtained by students after the application of the STAD model in their learning.

Research studies were done by Van $\mathrm{Wyk}^{28}$ and $\mathrm{Jacobs}^{29}$ in the usage of STAD as a learning method had been applied properly in several research projects. There is an increase in the total quantity of students who achieved MLMS in the cycle. Understanding that is still teacher-centered is considered as an important basis for reduced student social research learning outcomes in the pre-cycle because the training process in this subject is usually monotonous and boring. Students were shown how to higher understand learning by grouping and discussing with friends. Producing students to be less enthusiastic and understanding when resolving social research questions.

The STAD as a cooperative method was introduced and developed by Robert E. Slavin and friends from John Hopkins University, United States. ${ }^{30}$ This method drew 122 studies on the influence of cooperative, competitive, and individualistic goal structures on student achievement and productivity in a sample of schools in North America in the early 1980s. ${ }^{31}$ Teachers who can use cooperative learning

\footnotetext{
${ }^{27}$ Budi Murtiyasa and Septia Nurul Hapsari, "The Effect of TAI and STAD Strategy towards Learning Outcomes Reviewed from Mathematical Communication Skill," Universal Journal of Educational Research 8, no. 6 (June 2020): 2406-15, https://doi.org/10.13189/ujer.2020.080625; I Damopolii and S R Rahman, "The Effect of STAD Learning Model and Science Comics on Cognitive Students Achievement," Journal of Physics: Conference Series 1157 (February 2019): 022008, https://doi.org/10.1088/17426596/1157/2/022008; M L Nasution and N Hafizah, "Development of Students' Understanding of Mathematical Concept With STAD Type Cooperative Learning Through Student Worksheets," Journal of Physics: Conference Series 1554 (May 2020): 012035, https://doi.org/10.1088/1742-6596/1554/1/012035. ${ }^{28}$ Micheal M Van Wyk, "The Effects of the STAD-Cooperative Learning Method on Student Achievement, Attitude and Motivation in Economics Education," Journal of Social Science 33, no. 2 (2012): 261-70.

${ }^{29}$ M Jacobs, N Gawe, and N Vakalisa, Teaching-Learning Dynamics: A Participative Approach for OBE (Cape Town: Heinemann Publishers, 2003).

${ }^{30}$ Wyk, "The Effects of the STAD-Cooperative Learning Method on Student Achievement, Attitude and Motivation in Economics Education," 2012.

31 Ishtiaq, Zuraina, and Salem, "The Effects of Student Teams Achievement Division (STAD) on Motivation of Saudi EFL Adult Learners."
} 
strategies well can ask students to take an approach to teach so that they can assist other students to understand those subjects. ${ }^{32}$ Cooperative learning is a form of instruction that makes it possible for learners to work together as a team to help each other enjoy learning experiences. Because of the gaps, students should educate cooperative learning by actively designing successive experiences to enjoy each other such that not only instructors and textbooks and therefore fellow students are learning tools. So the teacher is just a facilitator in the learning process. ${ }^{33}$ Based on these approaches, some techniques have been developed. Student TeamsAchievement Divisions is one of the strategies in this teaching model. ${ }^{34}$

This STAD learning method is the simplest cooperative learning method. Because this method can be used in all levels of class, curriculum, and various kinds of learning objectives. This method is student-centered which is expected to make students understand and easier to learn the content of the learning delivered by the educator. It can be used from two to twelve at any grade level where there are single correct responses. ${ }^{35}$ According to Robert E. Slavin, in a learning group, four group members are selected based on differences in gender, ethnicity, and performance levels. ${ }^{36}$ After the teacher presents the lesson, students can work together with team members who can master the material provided. Furthermore, they will be given a quiz with individual scores to ensure understanding of the material they are good at. The scores obtained by each student are then added up and made into the team's score. The STAD learning method focused on students' understanding of doing work with others, respect the views of others and the meaning of diversity. Each group was given the possibility to make the title of every group relating to their wishes. Then regularly, they are given learning materials that must be perfected by all students of each group. Each student must do the test individually on the teaching material without help from other students. The students' scores are calculated from students' scores received by students on worksheets or assignments which are then compared

\footnotetext{
${ }^{32}$ Scott C. Griffith, "Cooperative Learning Techniques in The Clasroom," The Journal of Experiential Education 13, no. 2 (1990): 1-4.

${ }^{33}$ Ahmad Hanafi and Ismet Basuki, "Student Team Achievement Divisions: Its Effect on Electrical Motor Installation Knowledge Competence," IOP Conference Series: Materials Science and Engineering 336 (April 2018): 012025, https://doi.org/10.1088/1757-899X/336/1/012025.

${ }^{34}$ Sophia Fithri Al-Munawwarah, "The Implementation of Cooperative Learning: Student TeamsAchievement Divisions Technique in Teaching Reading Comprehension (A Case Study in a Class of Eighth Grade Students at One Public School in Bandung)," Journal of English and Education 1, no. 2 (2013): 8289.

${ }^{35}$ Slavin, Using Student Team Learning. The Johns Hopkins Team Learning Project.

${ }^{36}$ Slavin, "Outcome-Based Education Is Not Mastery Learning."
} 
with items or scores produced previously. Each student competes with others and gets an evaluation centered on which effectively the group is performing. The group is just a stage valued from items calculated inside their semester which is a real level of continuous evaluation. ${ }^{37}$ That finding proves that the STAD approach features a positive influence on students' social life. ${ }^{38}$

The STAD learning method, as interpreted based on the aforementioned definition, is an active learning method for small groups of class participants. Since in STAD, by assisting each other, students function heterogeneously together with some participants in each community. Here are four theories that underlie cooperative learning.

\section{1) The Vygotskian Perspective}

The Vygotsky priority is the Zone of Proximal Development (ZPD), which uses social connections with more knowledgeable individuals to advance development. The theory of Vygotsky suggests that we first learn from individual-to-person experiences and then individually through an internalization mechanism that leads to profound learning. ${ }^{39}$ Krashen's description of how second language learning happens is feedback theory. The learner advances and evolves in the 'natural order' according to this theory as he provides input' in the second language, which is one step above his present level of linguistic competence. Although not all learners can be at the same degree of linguistic competence at the same time, Krashen suggests that the secret to developing a syllabus is normal communicative feedback, thereby ensuring that each learner receives several $\mathrm{I}+1$ ' inputs suitable for the current stage of their linguistic competence. ${ }^{40}$

2) The Piagetian Perspective

Piaget's hypothesis claims that cognitive development contributes to learning. ${ }^{41}$ Learning arising from social experiences leads to cognitive development. A significant aspect of Piaget's philosophy of learning and thinking growth is that they require the involvement of learners.

\footnotetext{
${ }^{37}$ Wyk, "The Effects of the STAD-Cooperative Learning Method on Student Achievement, Attitude and Motivation in Economics Education," 2017.

38 Wyk.

${ }^{39}$ Robin Fogarty, “Architects of the Intellect,” Educational Leadership 57, no. 3 (1999): 76-78.

${ }^{40}$ Ricardo E. Schütz, "Stephen Krashen's Theory of Second Language Acquisition,” sk.com.br, 2019, https://www.sk.com.br/sk-krash-english.html.

${ }^{41}$ Tsailing Liang, "Implementing Cooperative Learning in Efl Teaching: Process and Effects" (National Taiwan Normal University, 2002), https://www.asian-efl-journal.com/Thesis_Liang_Tsailing.pdf.
} 
3) Bandura's Social Learning Theory

The theory of social learning speaks about how environmental and cognitive variables combine to shape learning and human behavior. This focuses on learning that happens in a social setting. It suggests that individuals learn from each other, including principles such as learning to observe, mimic, and model. ${ }^{42}$ People acquire knowledge of rules, skills, techniques, values, and behaviors by watching other persons.

\section{4) Constructivism}

It sees second language learning or knowledge as close to other forms of learning or knowledge, including other cognitive theories. ${ }^{43}$ Perhaps the most important contribution to constructivism is to emphasize student-centered learning. ${ }^{44}$ The philosophy of constructivism looks at the way a learner thinks. ${ }^{45}$ It has a clear relevance, thus to school. Constructivists assume that when a learner is fully involved, he learns better. In their world and in the course of acquiring knowledge and extracting meaning from these objects and events, students are seen as individuals who behave on objects and events. This hypothesis suggests that, through their interactions, humans construct awareness and meaning. ${ }^{46}$

As a form of cooperative learning, the steps of STAD are as follows: a) Establish a group of individuals with different in a heterogeneous group; a) The teacher provides a lesson; c) The teachers gave the task to the team to be performed by team members. Until all members of the group understand, the members know how to explain to other members; d) The teacher provides a test to all students at the school of answering the test must not help each other; e) Offer additional review; f) Conclusion. ${ }^{47}$ The researcher can also assume that cooperative learning is student-centered learning and an instructorfacilitated teaching method in which a small team of students is responsible for all team members' own learning and learning. This grouping approach is assumed to encourage each group's participants to get a high score.

\footnotetext{
${ }^{42}$ Sherry D. Lyons and Zane L. Berge, "Social Learning Theory," in Encyclopedia of the Sciences of Learning (Boston, MA: Springer US, 2012), 3116-18, https://doi.org/10.1007/978-1-4419-1428-6_1257.

${ }^{43}$ Lyons and Berge.

44 Dennis W. Cheek, Thinking Constructively About Science: Technology and Society Education (New York: State University of New York Press, 1992).

${ }^{45}$ Liang, "Implementing Cooperative Learning in Efl Teaching: Process and Effects."

${ }^{46}$ Liang.

${ }^{47}$ Hanafi and Basuki, "Student Team Achievement Divisions: Its Effect on Electrical Motor Installation Knowledge Competence."
} 
The main intention behind STAD is to boost and increase student performance. ${ }^{48}$ Moreover, STAD has five major components, including (a) class presentations, (b) teams, (c) quizzes, (d) individual grades for progress, and (e) appreciation of teams. ${ }^{49}$ The instructor designs a lesson plan by using the STAD method while preparing a lesson. The lesson plan applies to the standard competency and intrinsic competence of the primary school program. Besides, the instructor uses such formats, such as recounting documents, photographs, and worksheets, that are acceptable for the materials. ${ }^{50}$

\section{Conclusion}

Based on the research conducted, it can be concluded that the applying of the STAD learning method is quite effective in increasing fourth-grader elementary student scores. The use of the STAD learning method on social science subject focused has been proven can improve students' learning outcomes accomplished. It is proven by the substantial upsurge in scores achieved by students from pre-cycle to cycle I. In the precycle stage, students who accomplished MLMS reached 14 students or $66.7 \%$. Meanwhile, in the application form of cycle I, the students who reached MLMS successfully were 17 students or $80.9 \%$. Predicated on these results, shows when the implementation of the STAD learning method can help the achievement of learning process criteria between students and teachers can be classified as "excellent". It can indeed increase their knowledge of the challenge in the team by letting students determine their position.

This research is limited to the implementation of a single case study. Future research that can be carried out includes the implementation of multi-case studies from several schools with different geographic and cultural locations, the implications of multi cases from several different class levels, how to integrate with distance learning, virtual reality, augmented reality, and mixed reality.

\section{References}

Al-Munawwarah, Sophia Fithri. "The Implementation of Cooperative Learning: Student Teams-Achievement Divisions Technique in Teaching Reading Comprehension (A

\footnotetext{
${ }^{48}$ Wyk, "The Effects of the STAD-Cooperative Learning Method on Student Achievement, Attitude and Motivation in Economics Education," 2017.

${ }^{49}$ Robert E. Slavin, Cooperative Learning: Theory, Research and Practice (2nd Edition), 2nd ed. (Needham Heights, MA: Allyn and Bacon, 1995).

50 Al-Munawwarah, "The Implementation of Cooperative Learning: Student Teams-Achievement Divisions Technique in Teaching Reading Comprehension (A Case Study in a Class of Eighth Grade Students at One Public School in Bandung)."
} 
Case Study in a Class of Eighth Grade Students at One Public School in Bandung)." Journal of English and Education 1, no. 2 (2013): 82-89.

Aqib, Z, S Jaiyaroh, E Diniati, and K Khotimah. Penelitian Tindakan Kelas Untuk Guru SD, SLB, Dan TK. Bandung: Yrama Widya, 2009.

Arikunto, Suharsimi. Prosedur Penelitian. Jakarta: Rineka Cipta, 2013.

Astuti, Yupik Puji. "The Use Of Student Team Achievement Division (STAD) To Improve The Students Reading Comprehension Practice." English Education Journal 4, no. 1 (2014): 2-8.

Bhatnagar, Roli. "Challenges in Teaching and Learning of Social Science -The Dual Perspective." PEOPLE: International Journal of Social Sciences 4, no. 3 (December 10, 2018): 519-32. https://doi.org/10.20319/pijss.2018.43.519532.

Cheek, Dennis W. Thinking Constructively About Science: Technology and Society Education. New York: State University of New York Press, 1992.

Churchill, Larry R. "What Skills Should Be Taught in Health Humanities Education?" Rupkatha Journal on Interdisciplinary Studies in Humanities 12, no. 6 (December 15, 2020). https://doi.org/10.21659/rupkatha.v12n6.01.

Curran, F. Chris, and James Kitchin. "Early Elementary Science Instruction: Does More Time on Science or Science Topics/Skills Predict Science Achievement in the Early Grades?" AERA Open 5, no. 3 (July 3, 2019): 233285841986108. https://doi.org/10.1177/2332858419861081.

Damopolii, I, and S R Rahman. "The Effect of STAD Learning Model and Science Comics on Cognitive Students Achievement." Journal of Physics: Conference Series 1157 (February 2019): 022008. https://doi.org/10.1088/17426596/1157/2/022008.

Endayani, H. "Pengembangan Materi Ajar Ilmu Pengetahuan Sosial.” Jurnal Program Studi Pendidikan Ilmu Pengetahuan Sosial FITK UIN SU Medan 1 (2017).

Fogarty, Robin. “Architects of the Intellect.” Educational Leadership 57, no. 3 (1999): 76-78.

Gillies, Robyn M. "Cooperative Learning: Review of Research and Practice.” Australian Journal of Teacher Education 41, no. 3 (2016): 39-54.

Griffith, Scott C. "Cooperative Learning Techniques in The Clasroom." The Journal of Experiential Education 13, no. 2 (1990): 1-4.

Hamza AKENGIN, and Meltem Elif CENDEK. "A Study of Students' Opinions About History Subjects in the Social Studies Curriculum." Journal of Literature and Art Studies 7, no. 10 (September 20, 2017). https://doi.org/10.17265/21595836/2017.10.016.

Hanafi, Ahmad, and Ismet Basuki. "Student Team Achievement Divisions: Its Effect on Electrical Motor Installation Knowledge Competence." IOP Conference Series: Materials Science and Engineering 336 (April 2018): 012025. https://doi.org/10.1088/1757-899X/336/1/012025.

Hayatunisa, Linta. "Student Teams Achievement Divisions (STAD) Technique In Teaching Writing Narrative Text." Journal of English and Education 2, no. 1 (2014): $17-26$. 
Ishtiaq, Muhammad, Ali Zuraina, and Muhammad Salem. "The Effects of Student Teams Achievement Division (STAD) on Motivation of Saudi EFL Adult Learners." International Journal of Language Education and Applied Linguistics (IJLEAL) 3 (2015): 11-24. https://doi.org/10.15282/IJLEAL.V3.471.

Iskandar, Akbar, Muhammad Rizal, Nuning Kurniasih, Dian Utami Sutiksno, and Agung Purnomo. "The Effects of Multimedia Learning on Students Achievement in Terms of Cognitive Test Results The Effects of Multimedia Learning on Students Achievement in Terms of Cognitive Test Results." In Journal of Physics: Conference Series, Vol. 1114. IOP Publishing, 2018.

Iskandar, Dadang, Lutma Ranta Allolinggi, and Acep Roni Hamdani. "Analysis Learning Social Science Charged The Values Of Entrepreneurship In Primary School.” Jurnal Pendidikan Dasar Indonesia 2, no. 1 (2017): 9-12.

Jacobs, M, N Gawe, and N Vakalisa. Teaching-Learning Dynamics: A Participative Approach for OBE. Cape Town: Heinemann Publishers, 2003.

Johnson, D, R Johnson, M Stanne, and A Garibaldi. "Impact of Group Processing on Achievement in Cooperative Groups." Journal of Social Psychology 130 (1990): 507-16.

Liang, Tsailing. "Implementing Cooperative Learning in Efl Teaching: Process and Effects." National Taiwan Normal University, 2002. https://www.asian-efljournal.com/Thesis_Liang_Tsailing.pdf.

Lyons, Sherry D., and Zane L. Berge. "Social Learning Theory." In Encyclopedia of the Sciences of Learning, 3116-18. Boston, MA: Springer US, 2012. https://doi.org/10.1007/978-1-4419-1428-6_1257.

Murtiyasa, Budi, and Septia Nurul Hapsari. "The Effect of TAI and STAD Strategy towards Learning Outcomes Reviewed from Mathematical Communication Skill." Universal Journal of Educational Research 8, no. 6 (June 2020): 2406-15. https://doi.org/10.13189/ujer.2020.080625.

Narmaditya, Bagus Shandy, Winarning, and Dwi Wulandari. "Impact of Problem-Based Learning on Student Achievement in Economics Course." Classroom Action Research Journal 1, no. 1 (2017): 1-11. https://doi.org/10.17977/um013v1i12017p1.

Nasution, M L, and N Hafizah. "Development of Students' Understanding of Mathematical Concept With STAD Type Cooperative Learning Through Student Worksheets." Journal of Physics: Conference Series 1554 (May 2020): 012035. https://doi.org/10.1088/1742-6596/1554/1/012035.

Rakhman, Anita, and Isry Laila Syatroh. "The Analysis Of Students' Team Achievement Divisions (STAD) Used In Learning Practice Of Translating And Interpreting." ELTIN Journal 3, no. 2 (2015).

Schütz, Ricardo E. "Stephen Krashen's Theory of Second Language Acquisition." sk.com.br, 2019. https://www.sk.com.br/sk-krash-english.html.

Sharan, S. "Cooperative Learning." Review of Educational Research 50, no. 2 (1995): $315-45$.

Slavin, Robert E. Cooperative Learning: Theory, Research and Practice (2nd Edition). 2nd ed. Needham Heights, MA: Allyn and Bacon, 1995. 
—. "Developmental and Motivational Perspectives on Cooperative Learning: A Reconciliation." Child Development 58 (1987): 1161-67.

_ . "Outcome-Based Education Is Not Mastery Learning." Educational Leadership 51, no. 6 (1994): 14-15.

- Using Student Team Learning. The Johns Hopkins Team Learning Project. Center for Research on Elementary and Middle Schools, 1986.

Suci, Sayyida Hanim Ahida, Elsa Rosyidah, Nur Asitah, Nurul Aini, Arie Widya Murni, Fatkul Anam, Agung Purnomo, Sulfikar Sallu, Indrya Mulyaningsih, and Arlis Dewi Kuraesin. "Learning from Picture and Picture Action Research: Enhancement of Counting Ability on Division of Numbers for Primary School Students." In Journal of Physics: Conference Series. Aceh: IOP Publishing, 2018. https://doi.org/10.1088/1742-6596/1114/1/012044.

Sudijono, A. Pengantar Evaluasi Pendidikan. Jakarta: Raja Grafindo, 2003.

Susanto, Herry Agus, and Utami Murwaningsih. "Improving Students' Activity In Mathematics Communication Trough Metacognitive Learning Approach Based On Lesson Study." International Journal of Education and Research 3, no. 2 (2015): 169-80.

Wyk, Micheal M Van. "The Effects of the STAD-Cooperative Learning Method on Student Achievement, Attitude and Motivation in Economics Education." Journal of Social Science 33, no. 2 (2012): 261-70.

- "The Effects of the STAD-Cooperative Learning Method on Student Achievement, Attitude and Motivation in Economics Education." Journal of Social $\begin{array}{lllll}\text { Sciences } & 33, & 2 & \text { no. }\end{array}$ https://doi.org/https://doi.org/10.1080/09718923.2012.11893104.

Zahroh, A. Membangun Kualitas Pembelajaran Melalui Dimensi Profesionalisme Guru. Bandung: Yrama Widya, 2015. 